\title{
LITERARY AND \\ POLITICAL REVIEWS
}

576 AFRICA QUARTERLY : A Journal of African Affairs. Indian Council for Africa, Nyaya Marg, Chankayapuri, New Delhi, India. 4. Annual $£ 3$.

"Devoted to a study and objective understanding of African affairs. It publishes contributions from outstanding writers, experts and specialists on various political, economic, social, cultural and literary subjects of interest to the people of Africa. Apart from these it carries documentation on different specialised African subjects." Book reviews.

577 EAST AFRICA JOURNAL. East African Publishing House, PO Box 30571, Nairobi, Kenya. 12. Annual Sh 30.

"East Africa's leading magazine of informed opinion brings you articles relevant to all aspects of East Africa's political, cultural and economic development. Every January and July there is a special literary issue GHALA."

578 ECONOMIC AND POLITICAL WEEKLY - see Economics

579 INDIAN REVIEW. 2A, Cathedral Road, Madras 86. 12. Annual £2. Literary and political periodical "devoted to the discussion of all topics of interest."

580 TRANSITION. Transition Ltd, Airport Box 9063, Accra, Ghana. International Association for Cultural Freedom. 6. Amnual £2.05. Literary and political articles from international contributors on Africa.

581 UNITED ASIA: International Magazine of Afro-Asian Affairs. 12, Rampart Row, Bombay 1. 6. Annual $\$ 5$.

"Deals with all subjects of a pre-eminently Asian and African interest - political, economic, social and cultural - both historical and contemporary." 